\title{
Patterns and Mechanisms of Ant Diversity in Two Types of Land Use within Protected Forest Area Sirimau City of Ambon Maluku Province
}

\author{
Fransina Latumahina \\ Faculty of Agriculture, Pattimura University, Indonesia \\ Pieter J. Kunu \\ Faculty of Agriculture, Pattimura University, Indonesia \\ Tekat Dwi Cahyono \\ Faculty of Agriculture, Darusallam University Ambon, Indonesia
}

\begin{abstract}
Ants are the biodiversity constituent of $30 \%$ of the total insect biomass, very sensitive to changes in habitat structure and the environment in which they live can be an indicator of habitat destruction and ecosystem stability. The research was carried out in Sirimau Protected Forest area of Ambon City on two types of land use - each of secondary dryland and dryland farming from August to December 2012. The objective of the study was to know the structure of the ant community in two types of land use and to measure the pattern of ant distribution and diversity. Measurement of ant diversity using the Transect Line Plot method through a sampling system of a population sample with a sample plot approach that is on a line drawn across each type of land use using three Pitfall Trap (PT) methods or trap trap, Bait Trap BT) used Sugar and Tuna as feed and Hand Collecting (HC) method (Hasimoto, 2001) and collected with $\mathbf{7 0 \%}$ alcohol preservation. Determination of ant species diversity and ant typeness in each type of land use using Shanon-Wienner index with the help of Ecological Methodology 2nd Edition (Krebs, 2000), and Margalef index (Ludwig and Reynold, 1988). The results of the study found that the number of individuals on the secondary dry land was 47,672 dominated by Meranoplus bicolor and Crematogaster ampularis and on dry land agriculture of 65,413 dominated by Polirachis belicossa and Echinopla lineata-lineata. The diversity index in August in the secondary drylands was 3.33 and 3.31 in September while on dryland farms were 3.67 in August and 3.59 in September were high.
\end{abstract}

Keywords: Ants, Diversity, Meranoplus bicolor, Crematogaster ampularis, Polirachis belicossa, Echinopla lineata - lineata.

\section{INTRODUCTION}

The results of the 2010 satellite imagery interpellation by the Ambon City Forestry Office showed a change in land use within the Sirimau protected forest area where an area of 86.48 ha was found, 300.12 ha of primary dryland, 448.58 ha of secondary dryland, dryland agriculture mixed with the widest area 764.86 ha and shrubs covering an area of 2,161.51 ha (Anonymous, 2010). The transfer of functions occurring within this protected forest area leads to alleged changes in biodiversity of both flora and fauna that will lead to the occurrence of habitat degradation and fragmentation

One of the organisms of biodiversity in the ecosystem is the ants. Ants (Hymenoptera: Formicidae) are insects found in almost every type of ecosystem except the polar regions. In tropical ecosystems ants can account for more than $30 \%$ of total insect biomass and have 
various roles in the ecosystem (Bolton, 1994). Ants are very sensitive to changes in the habitat structure and environment in which they live and have different adaptability capabilities in each type of habitat (Andersen, 1977). Ants are a group of land animals that dominate tropical climates and can be an indicator of habitat destruction and a key indicator in measuring diversity of insects (Brown et al, 2000).

The diversity of ants in the forest will be an indicator of the level of stability of the forest ecosystem where the higher the level of ant diversity, the food chain and ecological processes together with other biotic components such as predation, parasitism, competition, symbiosis and predation in the forest ecosystem will be more complex and varied so as to have the chance to create balance and stability (Mejer, 2006). High diversity suggests a steady ecosystem balance because it has a high degree of elasticity to shocks in otherwise ecosystem ecosystems with low diversity indicating a pressure that results in degradation of ecosystem quality (Odum, 1998). This study is expected to explain the structure and composition of ant diversity as a result of the transfer of forest function to two types of land use within the Sirimau protected forest area of Ambon City.

\section{Research purposes}

The purpose of this research are:

1. Knowing the structure of the ant community in two types of land use within the Sirimau Protected Forest area of Ambon City.

2. Measuring the distribution pattern and ant diversity in two types of land use within the Sirimau Protected Forest area of Ambon City.

\section{Time And Location Research}

\section{METHODOLOGY}

The study was conducted from August to December 2011 on two types of land use within the Sirimau Protected Forest area of Ambon City each containing secondary dry land and dryland farming. This forest area is designated as Protected forest (Hutan Lindung) through the Decree of the Minister of Forestry Number 10327 / Kpts-II / 2002 with an area of 3,889 ha and geographically located between 128011'30 "-128016'36" BT and 3o19'15 "-3o44'10" The topographic LS is in a flat to very steep slope class.

Based on Geological Map of Ambon Island issued by Geology Directorate of Geology Department of Mines and Energy Geological Map of Ambon City in 2010, the geological condition of Protected Forest of Sirimau mountain is formed from 4 (four) rock formations namely 1) Kanike Formation (Center of protected forest), 2) Ambon Volcano Rock Formation (Tpav) in the form of loose material containing andesite lava, 3) dasit formation and 4) Breccia Formation Tuf. (Anonymous, 2010)

Some of the dominant vegetation types in this protected forest area are Ekaliptus (Eucalyptus $s p$ ), Acacia (Acacia mangium), Mountain Pine (Casuarina eguisetifolia), Tusam (Pinus merkusii Jung Et De Vriese) and Meranti (Shorea $s p$ ), Avocado (Persea americana), Duku (Langsium domesticum), Durian (Durio zibethinus), Gandaria (Buaea macrophila), Jambu air (Eugenia jambolana), Cashew (Anacardium ochidentale), Kedondong (Spondies pinnata), Mango (Manggifera indica), Coconut (Cocos nucifera) and Rambutan (Nephelium lappeceum). (Latumahina, 2006)

\section{RESEARCH PROCEDURE}

Measurement of ant diversity in two types of land use using the Transect Line Plot method through a sampling system of a population sample with a sample plot approach that is on a line 
drawn across each type of land use. Three sampling methods was used to take Ants. Those are Pitfall Trap (PT), Bait Trap (BT) using sugar and Tuna fish as a bait and method of Hand Collecting (HC) (Hasimoto, 2001). These three methods are chosen because they are easy to implement in the field with low cost and get accurate results. The Pitfall Trap method uses a plastic cup of $\pm 7 \mathrm{~cm}$ in diameter and a height of $\pm 10 \mathrm{~cm}$ containing $25 \mathrm{ml}$ of soapy water solution to attract the presence of ants. Pitfall Trap is planted as deep as $\pm 10 \mathrm{~cm}$ at every $20 \mathrm{~m}$ distance in each observation track, and then left for 1 hour after it is taken, collected and identified. The Bait Trap method uses feeds in the form of a sugar solution moistened on cotton and Tuna fish placed in plastic plates attached to two different trees as high as the observer at each $50 \mathrm{~m}$ distance on the observation path. Plates left for 1 hour then taken, collected in $70 \%$ alcohol and identified in the laboratory. Hand Collecting method is specially carried out on ants and nests that live around low plants, between rocks, ground surface, mound and wood fracture (Hashimoto, 2001).

The ants were collected with $70 \%$ alcohol preservation and were identified using a binocular stereo microscope up to the species level using some ant identification keys ie Identification Guide to The Ant Genera of the World (Bolton, 1997), Ants in Indonesia (Suputa and Hasimoto, 2010) and Ant Parataxonomic Training Book Course From ANeT at University Of Malaya Kuala Lumpur (Anonymous, 2005).

\section{DATA ANALYSIS}

Determining the level of ant diversity in each type of land use, the Shanon-Wienner index was used with the help of Ecological Methodology 2nd Edition (Krebs, 2000). Wealth of ant types in each type of land use is known using the Margalef index (Ludwig and Reynold, 1988). Similar species composition of ants in each type of land use were analyzed using the Sorenson (Index of Similarity) index (Magurran, 2004). This index is calculated using the Biodiv 97 program which is a macro software for Microsoft Excel (Messer, 1997).

\section{Composition of Ants on Each Type of Land Usage}

\section{RESULT AND DISCUSSION}

The composition of ants using three sampling methods can be seen in table 1 below

Table 1: Number of Individuals of Ants on Two Land Use Types In Sirimau Protected Forest Area Ambon

\begin{tabular}{cccccccccc}
\hline Type & BT & BT & BT & BT & HC & HC & PT & PT & Total \\
\hline Use & Fish & Fish & Sugar & Sugar & (Agst) & (Sept) & (Agst) & (Sept) & \\
\hline \multicolumn{1}{c}{ Land } & (Agst) & (Sept) & (Agst) & (Sept) & & & & & \\
\hline $\begin{array}{l}\text { Secondary } \\
\text { Dry Land }\end{array}$ & 2027 & 2281 & 1566 & 1818 & 15408 & 16555 & 3959 & 4058 & 47672 \\
\hline $\begin{array}{l}\text { Agricultural } \\
\text { Dry land }\end{array}$ & 2327 & 2450 & 2501 & 2722 & 20835 & 21195 & 6554 & 6829 & 65413 \\
\hline
\end{tabular}

Information : BT: Bait Trap, HC: Hand Collecting, PT: Pitfall Trap

The table above shows that the largest number of individuals found in dry land farming areas. The high number of individual ants in the dry land farming area is due to the sample size for this type of land is $11.7 \mathrm{~km}$ higher than the secondary dry land of only $7.82 \mathrm{~km}$. On the other hand, many of the ants found in dry land farming areas are thought to be a type of bush use providing a suitable habitat for ant life including the availability of adequate food and the temperature factor and moisture of the micro air in accordance with the life of the ants therein. This is in accordance with the opinion Rahmawati (2007) that macro fauna of land including 
ants will be more dominant in areas with appropriate food sources and climatic conditions that support. The optimum air temperature for ants for daily activities ranges from $27-29^{\circ} \mathrm{C}$.

The results of micro climate measurements on two types of land use show the average air temperature in dry land agriculture in August month of $28.1{ }^{\circ} \mathrm{C}-28.9{ }^{\circ} \mathrm{C}$ and in September ranged from $28.2^{\circ} \mathrm{C}-29.3{ }^{\circ} \mathrm{C}$. The air temperature in the secondary dry land area in the month of Agus is $28.1-28.7{ }^{\circ} \mathrm{C}$ and in September it reached $28.2{ }^{\circ} \mathrm{C}-28.9{ }^{\circ} \mathrm{C}$. Differences in air temperature also affect the life of ants, because at low temperatures the activity of feeding will decrease compared to high temperatures. On the other hand the availability of food sources ie vegetation is available in dry land farming areas are more varied and much preferred by ants because it is a fruit plant - a lot of sugar contained in a very liked by ants.

Based on the sampling method, it is found the largest number of species obtained by Hand collecting method followed by Pitfall Trap, Bait trap (Fish) and Bait Trap (Sugar). The high number of individuals and the number of species with Hand collecting method is caused by this method we can find the ants freely above the ground, behind the rocks, under the pile of wood, below litter and in vegetation. On the other hand the hand collecting method is quite effective because it is not limited by the number of sample plot points when compared to the other two methods using plot sampling in each type of land use. (Table 2)

Table 2: Number of Ant Types Based on Sampling Method

\begin{tabular}{lccccccccc}
\hline \multirow{2}{*}{ Tipe Lahan } & \multicolumn{2}{c}{ BT Ikan } & \multicolumn{2}{c}{ BT Gula } & \multicolumn{2}{c}{$\begin{array}{c}\text { Hand } \\
\text { Collecting }\end{array}$} & \multicolumn{2}{c}{ Pitfall Trap } & \multirow{2}{*}{ Jumlah } \\
\cline { 2 - 9 } & Agst & Sept & Agst & Sept & Agst & Sept & Agst & Sept & \\
\hline $\begin{array}{l}\text { Secondary Dry } \\
\text { Land }\end{array}$ & 13 & 15 & 13 & 15 & 21 & 21 & 18 & 20 & 136 \\
\hline $\begin{array}{l}\text { Agricultural Dry } \\
\text { Land }\end{array}$ & 17 & 18 & 18 & 18 & 34 & 31 & 24 & 21 & 181 \\
\hline \multicolumn{1}{c}{ Total } & 30 & 33 & 31 & 33 & 55 & 52 & 42 & 41 & 317 \\
\hline
\end{tabular}

The results of the primary data from the table above shows that the number of ant species on dry land farms is higher by Hand collecting method than in secondary dry land with other methods. For type of dryland farming in August it is dominated by Polirachis belicossa and September by Echinopla lineata - lineata. The high presence of these individuals is thought to be associated with a considerable source of food in dry land farming compared to secondary land of protein and glucose in fruit crops.

It is suspected that the ability to find food from Polirachis belicossa is higher than other species in the area so that it influences the reproduction activity of female ants to produce new individuals in the community. The other side of the level of competition between ant types in the area is allegedly low allowing ants to remain in stable condition. High levels of ant population in one habitat are affected by competition factors, especially food and cruising areas where stronger ant species will monopolize food sources and roaming areas. Usually ant Polirachis belicossa and Echinopla lineata - lineata. is a stronger ant species in maintaining their territory so that their colony is stronger and will contribute to competition for food sources. Brühl et al. (1998),

On secondary dry land is dominated by Meranoplus bicolor in August and Crematogaster ampularis in September. The dominance of these two species in the region is related to the availability of suitable food sources for them including Acacia mangium trees, Pulai (Alstonia scholaris) found very much in this secondary dry land area because these two trees produce nectar which has a very sweet taste favored by Meranoplus bicolor and Crematogaster 
ampularis. Research conducted by Graham.S.Law (2007) found that the ants of the genus Crematogaster and Meranoplus generally like trees that produce sweet liquids with protein and carbohydrate content.

\section{THE DIVERSITY OF ANTS IN THE AREA}

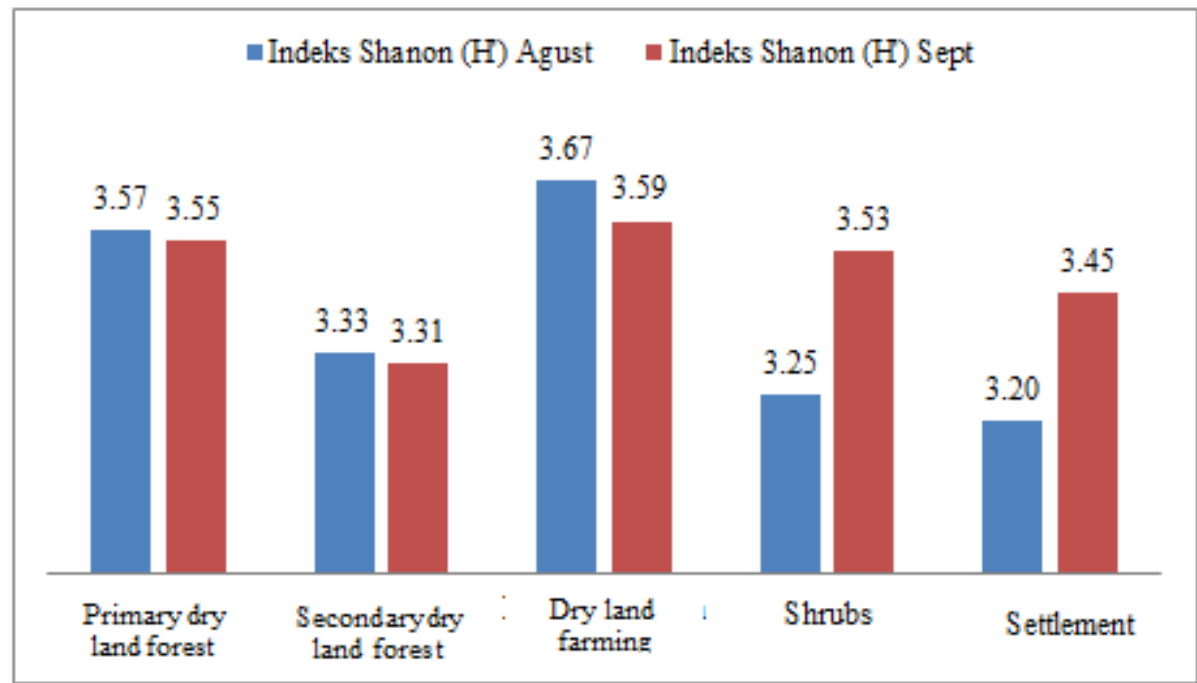

Graph 1. Diversity of Ants in Sirimau Protected Forest Area Ambon

The results of the graph above show that there are differences in the diversity between the two types of land use in two areas. Dry land farms have a higher diversity index than in the secondary dry lands of 3.67 in August and 3.59 in September which are high and in secondary dry land forests of 3.33 in August and 3.31 in September are also high. The value of this diversity index shows that in both areas ant diversity is very high with the spread of the number of individuals of each type high with the level of community stability is also quite high. This is allegedly related to the variance of the availability of food sources in dry land farming areas is higher than in secondary dry land. In the dry land farming area, there are many fruit trees that produce nectar which is highly favored by ants such as Acacia mangium, Cempedak (Arthocarpus chempeden), Belimbing (Averhoa carambolla), Guava (Psidium guajava), Rambutan (Nephelium lapaceum) and other types of protein-producing trees. On the other hand, the micro-temperature and humidity factors in the region also influence the variation of ant life, because the optimum temperature and humidity for each ant is not always the same. Rahmawati (2007) said the ants can live well in the temperature range 27 - 29 oc for the tropics.

Differences in temperature and humidity in the area occur as a result of rainfall and solar radiation factor which in August to September 2011 in Ambon city is quite high ie $771 \mathrm{~mm} /$ day with 16 days of rain in August and $233.7 \mathrm{~mm} /$ day with 14 rainy days reached 76\%. The solar radiation in August was 52\% and September was 66\%. This microclimate change greatly affects the presence of ants in the area because it will affect the population density which in turn affects the type of ants in the region. On a rainy day the species of ants will hide in the ground for some time and will continue if the rain has stopped and the air temperature returns warmer (Chung and Maryati, 1996).

Disturbance in the forest area also affects the diversity of ants living therein, because changes in the ecosystem will directly affect the vegetation structure as a source of food and land as a place to build a nest. (Chung and Maryati, 1996) suggest that habitats impaired by human presence will have a lower ant diversity when compared to undisturbed habitats. 


\section{CONCLUSION}

Some conclusions in this study are:

1. The types of ants that dominate dryland agriculture are Polirachis belicossa and Echinopla lineata - lineata and on secondary dry land dominated by Meranoplus bicolor and Crematogaster ampularis types.

2. The composition of ant species and diversity in two types of land use is influenced by the extent of the sampling plots, the availability of food sources, the microclimate, the presence of other competitors, the intensity of the disturbance in the area and the extent of the colony's roaming area.

3. The transfer of regional functions will affect the pattern of ant diversity in the region.

\section{SUGGESTION}

Some suggestions that can be submitted in this research are:

1. Further research is needed on other types of land use within the Sirimau Protected Forest area of Ambon City

2. Efforts to conserve the area should be done in order to maintain the stability of ant communities in the region.

\section{References}

Andersen. (1977). Ants as indicators of ecosystem restoration following mining: a functional group approach. Pp. 319-325. In Hale, P. and D. Lamb (eds.) Conservation outside nature reserves. Centre for Conservation Ecology, The University of Queensland.

Anonymous. (2010). Laporan inventarisasi Hutan Kota Ambon [Ambon City Forest inventory report]. Ambon City Forestry Office.

Bolton. (1994). Taxonomy and biology ants. Journal Of Natural history, 23, 1267-1308.

Brown. (2000). Diversity of Ants. In ANTS. Standard Method for Measuring and Monitoring Biodiversity. Edited by Agosti, D., Majer, J. D, Alonso, L, E \& Schultz, T. R. Smithsonian Institution.

Bruhl, C. A., Gunsalam, G., \& Linsenmair, K. E. (1998). Stratification of ants (Hymenoptera, Formicidae) in primary rain forest in Sabah, Borneo. Journal of Tropical Ecology, 14, 285-297.

Chung \& Maryati (1996). A comparative study of the ant fauna in a primary and secondary forest in Sabah, Malaysia. In Edward, D. S., Booth, W. E \& Choy, S.C (eds). Tropical rainforest research-Current Issues, pp 357-366. Kluwer Academic Publisher, Dodrecht, Nederlands.

Hasimoto (2001). How to design an inventory method for ground-level ants in tropical forest. Nature and Human Activities, 6, 25-30.

Latumahina. (2006). Inventarisasi jenis serangga dalam kawasan hutan lindung sirimau Kota Ambon [Inventory of insect species in protected forest area sirimau Kota Ambon]. Student research report. Faculty of Agriculture Pattimura University Ambon.

Mejer. (1997). The use of pitfall traps for sampling ants - a critique. Memoirs of the Museum of Victoria 56(62): 323-329

Mejer, 2006. An improved pitfall trap for sampling ants and other epigaeic invertebrates. Journal of the Australian Entomological Society, 17, 261-262. 